[Bull. Agr. Chem. Soc. Japan, Vol. 21, No. 4, p. 235 238, 1957]

\title{
Enzymatic Resolution of Racemic Amino Acids
}

\author{
Part V. Preparation of L-and D-Isomers of Tryptophan, Leucine and \\ Alanine by Enzymatic Resolution of the Acetylderivatives \\ of DL-Amino Acids with Mold Acylase
}

By Kimiyo Michi and Harumi Tsuda

The Laboratory of Food and Nutrition of Japan Women's University, Tokyo

Received February 11, 1957

\begin{abstract}
The mold acylase of Aspergillus and Penicillium which hydrolyzes, asymmetrically, only the $\mathrm{L}$-isomer of $\mathrm{N}$-acylated $\mathrm{DL}$-amino acids has been purified previously by the present authors. In this paper the application of asymmetric hydrolysis with the mold acylase to the resolution of $\mathrm{N}$-acylated DL-amino acids, namely, acetylderivatives of DL-tryptophan, DL-leucine and DL-alanine is described. By this enzymatic procedure, the above amino acids were resolved in relatively good yields. It has been noted that the use of the mold acylase is suitable for general resolution of amino acid enantiomorphs of high optical purity.
\end{abstract}

The purification method of the mold acylase of Aspergillus and Penicillium which acts asymmetrically on the L-isomer of $\mathrm{N}$-acylated DLamino acids, has been improved by the present authors ${ }^{1,2)}$. It has been noted that the enzyme is relatively easily prepared from the extract of inexpensive molded bran by fractionation with ammonium sulfate and acetone, precipitation with rivanol and elution from the rivanol-enzyme complex. The optical specificity of this enzyme to $\mathrm{N}$-acylated DL-amino acids was previously ${ }^{1,3)}$ employed for the resolution of several racemic amino acids, namely, DL-valine, DL-glutamic acid, DL-phenylalanine and DL-methione. The present investigation is an extension of this procedure, which is based on the use of the optical specificity of mold acylase, for the resolution of the $\mathrm{N}$-acetylderivatives of $\mathrm{DL}$ tryptophan, DL-leucine and DL-alanine.

\section{EXPERIMENTAL}

Enzymatic Assay The purified enzyme solution

1) K. Michi and H. Nonaka, This Bulletin, 19, 153 (1955).

2) K. Michi and H. Tsuda. This Bulletin, 21, 18 (1957).

3) K. Michi and H. Nonaka, J. Agr. Chem. Soc. Japan, 28, 346 (1954). used for the resolution of acetyl-DL-amino acids was prepared, as described previously2), by fractionation with ammonium sulfate and acetone, precipitation with rivanol and elution from the rivanol-enzyme complex with phosphate buffer; the final enzyme precipitate obtained by saturation of ammonium sulfate from the above eluate was dissolved in water and dialyzed overnight.

Initial rates of hydrolysis of the $\mathrm{N}$-acetylderivatives* of DL-tryptophan, DL-leucine and DL-alanine with the

TABLE I

INITIAL HYDROLYTIC RATES OF ACETYL-DL-AMINO ACIDS

\begin{tabular}{llll} 
& \multicolumn{3}{c}{ Rate of Hydrolysis } \\
\cline { 2 - 4 } Substrates & Exp. I & Exp. II \\
Enzyme $0.5 \mathrm{ml}$. & $1 \mathrm{ml}$. & $0.5 \mathrm{ml}$. \\
yl-DL-phenylalanine & $1.55 \mathrm{mM}$ & $1.95 \mathrm{mM}$ & $1.25 \mathrm{mM}$ \\
yl-DL-tryptophan & & $1.98 \mathrm{mM}$ & \\
yl-DL-leucine & & $1.00 \mathrm{mM}$ &
\end{tabular}

Acetyl-DL-alanine $\quad 1.15 \mathrm{~mm}$

The reaction mixture was incubated at $38^{\circ} \mathrm{C}$ for one hour at $\mathrm{pH} 7.8$. This reaction mixture was composed of $0.5 \mathrm{ml}$ of $0.5 \mathrm{~m}$ acetyl-DL-amino acid, $1 \mathrm{ml}$ of $0.1 \mathrm{M}$ phosphate buffer of $\mathrm{pH} 7.8$ and $0.5 \mathrm{ml}$ (equivalent to $1 \mathrm{~g}$ of original molded wheat bran, $0.2 \sim$ $0.5 \mathrm{mg}$ of solid matter) or $1 \mathrm{ml}$ of the purified enzyme solution. The hydrolycic ate was measured by the optical density of ninhydrin reaction of the liberated amino acid expressed in terms of $m$ M of liberated amino acid.

* Purchased from General Biochemicals, Institute, U.S.A. 
purified mold acylase were determined, and the results are shown in Table I. The pH optima for the hydrolysis of acetyl-DL-tryptophan and acetyl-DL-leucine were found to be approximately $\mathrm{pH} 7.8$ for these acetyl-DL-amino acids. The $\mathrm{pH}$ optimum for acetylDL-alanine had previously been given as about $\mathrm{pH} 7.8$.

Resolution of Acetyl-DL-tryptophan Ten $g$ (0.041 mol) of acetyl-DL-tryptophan was dissolved in $500 \mathrm{ml}$ of water and neutralized by the addition of $2 \mathrm{~g}$ of calcium carbonate to about $\mathrm{pH}$ 7. To this aqueous

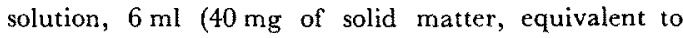
$70 \mathrm{~g}$ of molded bran) of purified enzyme was added to insure complete hydrolysis of the L-form of the acetylderivative and the mixture was incubated at $38^{\circ} \mathrm{C}$ under toluene for two days.

The digest was then treated with aqueous solution of the calculated amounts of oxalic acid to remove calcium. The filtrate through charcoal was evaporated in vacuo to a very small volume, and the residue taken up with alcohol was allowed to stand for 12 hours in a refrigerator. The precipitate, which is almost pure L-tryptophan, was filtered by suction and washed with absolute alcohol. The filtrate was evaporated to dryness and the residue was again taken up with $85 \%$ alcohol. When the mixture was allowed to stand in a refrigerator overnight, another crop of L-tryptophan was obtained.

The combined precipitates of L-tryptophan weighed $4 \mathrm{~g}$ (87\% of theo.). The purified amino acid recrystallized from water showed $[\alpha]_{0}^{20}-32.3^{\circ}$ (c 0.5 , water). Analysis, Found: $\mathrm{N}, 13.80$. Calcd. for $\mathrm{C}_{11} \mathrm{H}_{12} \mathrm{O}_{2} \mathrm{~N}_{2}$ : $\mathrm{N}, 13.72$.

Isolation of $\mathrm{D}$-Tryptophan The flitrate of $\mathrm{L}$ tryptophan was evaporated to dryness and the residue was washed with water. The water insoluble-precipitate of acetyl-D-tryptophan was taken up with $100 \mathrm{ml}$ of $2 \mathrm{~N}$ sulfuric acid and the solution was refluxed for 2 hours. The solution was diluted with equal volume of water and an aqueous baryta solution was added to remove sulfuric acid. The filtrate through charcoal was evaporated to dryness and the residue taken up with absolute alcohol was allowed to stand in a refrigerator overnight. The precipitate of D-tryptophan of $3 \mathrm{~g}(65.2 \%$ of theo.) was recrystallized from water. The purified D-tryptophan showed $[\alpha]_{D}^{20}+32.1^{\circ}(c 0.5$, water).

Analysis, Found: N, 13.85. Calcd. for $\mathrm{C}_{11} \mathrm{H}_{12} \mathrm{O}_{2} \mathrm{~N}_{2}$ : N, 13.72 .

Resolution of Acetyl-DL-leucine Ten $g$ ( 0.058 mol) of acetyl-DL-leucine were dissolved in $500 \mathrm{ml}$ of water and after addition of $2.8 \mathrm{~g}$ of calcium carbonate the mixture was incubated with an appropriate amount of purified enzyme (150 mg of solid matter, equivalent to $250 \mathrm{~g}$ of molded bran) at $38^{\circ} \mathrm{C}$., for two days.

The digest was treated with aqueous solution of oxalic acid to remove calcium. The filtrate was evaporated to crystallize L-leucine, warmed with 3 volumes of absolute alcohol and the mixture was allowed to stand in a refrigerator. L-Leucine thus obtained, amounted to $3.3 \mathrm{~g}(87 \%$ of theo,) and was recrystallized from water. L-Leucine showed $[\alpha]_{1}^{20}+15.65^{\circ}(\mathrm{c} 4,6 \mathrm{~N} \mathrm{H}$ Cl). Analysis, Found: N, 11.00. Calcd. for $\mathrm{C}_{6} \mathrm{H}_{13} \mathrm{O}_{2}$ $\mathrm{N}: \mathrm{N}, 10.68$.

Isolation of $\mathrm{D}$-Leucine The combined filtrates which had been separated from the L-leucine preparation were evaporated to dryness and taken up with a small amount of water. After standing in a refrigerator the crystallized acetyl-D-leucine was filtered. The precipitate which showed m.p. $185^{\circ} \mathrm{C}$. and a negative ninhydrin reaction $(5.5 \mathrm{~g}$ of wet substance) was refluxed with $100 \mathrm{ml}$ of $2 \mathrm{~N}$ sulfuric acid for two hours. The digest was treated with baryta to remove sulfuric acid as in the case of tryptophan. The filtrate was evaporated to dryness and the residue was taken up with absolute alcohol. The precipitate of D-leucine was washed with alcohol. It weighed $2.8 \mathrm{~g}$ (74\% of theo.) and was recrystallized from water. It showed $[\alpha]_{\mathrm{D}}^{20}-15.35^{\circ}(\mathrm{c} 4,6 \mathrm{~N} \mathrm{HCl})$, Analysis, Found : $\mathrm{N}, 10.67$. Calcd. for $\mathrm{C}_{6} \mathrm{H}_{13} \mathrm{O}_{2} \mathrm{~N}: \mathrm{N}, 10.68$.

Resolution of Acetyl-DL-alanine Ten $\mathrm{g} \quad(0.077$ mol) of acetyl-DL-alanine were dissolved in $500 \mathrm{ml}$ of water and neutralized with $3.5 \mathrm{~g}$ of calcium carbonate to $\mathrm{pH} 7$. An appropriate amount of acylase solution (70 $\mathrm{mg}$ in $10 \mathrm{ml}$ of water, corresponding to $120 \mathrm{~g}$ of molded bran) was added to the solution and the mixture was incubated under toluene at $38^{\circ} \mathrm{C}$., for two days.

At the end of the enymatic hydrolysis, the digest was treated with oxalic acid as described in the case of tryptophan. The filtrate was evaporated in vacuo to about $20 \mathrm{ml}$ and, after addition of absolute alcohol to $65 \%$ content, the mixture was allowed to stand in a refrigerator for 12 hours. The precipitate of $\mathrm{L}$ alanine which weighed $2.8 \mathrm{~g}(81 \%$ of theo.) was filtered and recrystallized from'a water-alcohol mixture. $[\alpha]_{\mathrm{D}}^{20}+14.63^{\circ}(\mathrm{c} 6,1 \mathrm{~N} \mathrm{HCl})$. Analysis, Found: $\mathrm{N}$, 15.69. Calcd. for $\mathrm{C}_{3} \mathrm{H}_{7} \mathrm{O}_{2} \mathrm{~N}: \mathrm{N}, 15.72$.

Isolation of D-Alanine The filtrate which had been separated from L-alanine preparation was evaporated and the residue was dissolved in absolute alcohol- 
acetone mixture and allowed to stand in a refrigerator. The precipitate was removed and the solution was evaporated. The residue which was almost pure acetyl-D-alanine was refluxed with $80 \mathrm{ml}$ of $2 \mathrm{~N}$ sulfuric acid for 3 hours.

The mixture was treated with baryta solution to remove sulfuric acid as described in the case of tryptophan. After evaporation of the filtrate, the residue was treated with alcohol. The precipitate of $\mathrm{D}$-alanine was filtered and recrystallized from $60 \%$ alcohol. The yield of D-alanine was $2.4 \mathrm{~g}$. (71\% of theo.) $[\alpha]_{\mathrm{D}}^{20}-$ $14.10^{\circ}$ (c6, $1 \mathrm{~N} \mathrm{HCl}$ ). Analysis, Found: $\mathrm{N}, 15.87$. Calcd. for $\mathrm{C}_{3} \mathrm{H}_{7} \mathrm{O}_{2} \mathrm{~N}: \mathrm{N}, 15.72$.

\section{DISCUSSION}

During the past several years, Greenstein et al. -9) have accomplished the preparation of $\mathrm{D}$ - and $\mathrm{L}$-isomers of most of the amino acids on a large scale by using renal acylase for the resolution of acylderivatives of all $\alpha$-amino acids except for the aromatic amino acids which are best resolved by employing pancreatic carboxypeptidase instead of the renal acylase.

The present authors have so far resolved seven DL-amino acids, namely, DL-valine, DLglutamic acid, DL-phenylalanine, DL-methionine, DL-tryptophan, DL-leucine and oL-alanine by substituting the mold acylase for the renal acylase and the carboxypeptidase. The present paper is concerned with the enzymatic resolution of acetylderivatives of the latter three racemic amino acids.

The initial hydrolytic rates of $\mathrm{N}$-acetyl-DLtryptophan, $\mathrm{N}$-acetyl-DL-leucine and $\mathrm{N}$-acetylDL-alanine were compared with that of acetylDL-phenylalanine which was best resolved

TABLE II

ENZyMatic Preparation of L-AND D-AMINo ACIDS by ASYMmETriC Hydrolysis OF N-ACyLderivatives OF DL-AMino ACIDS With MOLD ACYLASE

\begin{tabular}{|c|c|c|c|c|c|c|}
\hline DL-Amino Acid & $\begin{array}{l}\text { Derivative } \\
\text { employed }\end{array}$ & $\begin{array}{l}\text { Amino Acid } \\
\text { resolved }\end{array}$ & $\begin{array}{l}\text { Yield } \\
\%\end{array}$ & ${ }^{\circ} \mathrm{C}$ & {$[\alpha]_{\mathrm{D}}$} & $\begin{array}{l}\text { Data in } \\
\text { literature }\end{array}$ \\
\hline \multirow[t]{2}{*}{ DL-Valine } & \multirow[t]{2}{*}{ Chloroacetyl } & L-Valine & 89 & 24 & $+27.7(3.4 \%$ in $6 \mathrm{~N} \mathrm{HCl})$ & $+27.4^{57}$ \\
\hline & & D-Valine & 72 & 24 & $-27.6(\|)$ & $-27.1^{53}$ \\
\hline \multirow[t]{2}{*}{ DL-Glutamic Acid } & \multirow[t]{2}{*}{ Acetyl } & L-Glutamic acid & 95 & 28 & $+31.3(2.08 \%$ in $6 \mathrm{NHCl})$ & $+32.0^{52}$ \\
\hline & & D-Glutamic acid & 64 & 28 & $-31.1(" \prime)$ & $-31.9^{5)}$ \\
\hline \multirow[t]{2}{*}{ DL-Phenylalanine } & \multirow[t]{2}{*}{ Acetyl } & L-Phenylalanine & 83 & 20 & $-34.8(1.6 \%$ in water $)$ & $\left.-34.8^{6}\right)$ \\
\hline & & D-Phenylalanine & 70 & 20 & $+34.6(" \prime)$ & $+34.8^{6)}$ \\
\hline \multirow[t]{2}{*}{ DL-Methionine } & \multirow[t]{2}{*}{ Acetyl } & L-Methionine & 86 & 14 & $+23.42(2 \%$ in $6 \mathrm{~N} \mathrm{HCl})$ & $+23.4^{16)}$ \\
\hline & & D-Methionine & 61 & 14 & $-23.3(\prime \prime)$ & $-23.4^{10)}$ \\
\hline \multirow[t]{2}{*}{ DL-Tryptophan } & \multirow[t]{2}{*}{ Acetyl } & L-Tryptophan & 87 & 20 & $-32.3(0.5 \%$ in water $)$ & $-32.2^{8}$ \\
\hline & & D-Tryptophan & 65 & 20 & $+32.1(" \prime)$ & $+32.5^{6)}$ \\
\hline \multirow{2}{*}{ DL-Leucine } & \multirow{2}{*}{ Acetyl } & L-Leucine & 87 & 20 & $+15.65(4 \%$ in $6 \mathrm{~N} \mathrm{HCl})$ & $+15.9^{5)}$ \\
\hline & & D-Leucine & 74 & 20 & $-15.35(" \prime)$ & $-15.6^{5}$ \\
\hline \multirow{2}{*}{ DL-Alanine } & \multirow{2}{*}{ Acetyl } & L-Alanine & 81 & 20 & $+14.63(6 \%$ in $1 \mathrm{~N} \mathrm{HCl})$ & $+14.4^{5)}$ \\
\hline & & D-Alanine & 71 & 20 & -14.10( & $-14.4^{5)}$ \\
\hline
\end{tabular}

\footnotetext{
4) J.P. Greenstein et al., J. Biol. Chem., 178, 503 (1949).

5) J.P. Greenstein et al., J. Biol. Chem.. 179, 1169 (1949).

G) J.P. Greenstein et al., J. Biol. Chem., 180, 473 (1949).

7) J.P. Greenstein et al., J. Biol. Chem., 182, 451 (1950).

8) J.P. Greenstein et al., Arch. Biochem. Biopbys., 39, 108 (1952).

9) J.P. Greestein et al., J. Am. Chem. SoC., 72, 2812 (1950).

10) M. Brenner, Helv. Cbim. Acta., 32, 333 (1949).

* Data in the literature for all amino arids except methionine

are those reported by Greenstein et al.
}

previously, by the use of mold acylase. AcetylDL-tryptophan is susceptible for the mold acylase in the same degree of hydrolytic rate of acetyl-DL-phenylalanine as shown in Table I. Acetyl-DL-alanine is also a susceptible substrate for the mold acylase. The initial rate of hydrolysis which had been previously3) measured had in a lower value. The repeated 
measurement of the hydrolytic rate of acetylDL-alanine shows a rather high value. When compared with other amino acids, acetyl-DLleucine is relatively resistant for hydrolysis by the mold acylase. Therefore, the 2.5-fold amount of the enzyme for acetyl-DL-tryptophan must be employed for the resolution of acetyl-DL-leucine in order to insure complete hydrolysis. The amino acids which were so far resolved by the enzymatic procedure with the mold acylase by the present authors are listed in Table II.

The enzymatic resolution procedure with the mold acylase showed good yields of the L- and D-isomers of the amino acids which varied from 60 to $95 \%$ of the theoretical. Each amino acid is checked for its optical purity by measuring the optical rotation. As shown inTable II, the specific rotation of each amino acid was compared with those in the literature and these were found to be in good agreement with those given by Greenstein et al. $5,6,10)$

Since it became available to easily prepare the purified enzyme from inexpensive molded wheat bran as described previously, it seems that the use of mold acylase for the resolution of DL-amino acids can be extended to the resolution of all other racemic amino acids. This series of study is under way.

Acknowledgment The authors are grateful to Dr. S. Abe and Dr. H. Iizuka of the Microbiology Institute of University of Tokyo for kindly supplying Penicillium and Aspergillus and Miss Isobe for performing the microanalyses. The research was aided by a Grant from the Ajinomoto Company.

\section{SUMMARY}

(1) The enzymatic procedure of the asymmetric hydrolysis of $\mathrm{N}$-acylated DL-amino acids with the mold acylase was applied for the resolution of DL-tryptophan, DL-leucine and DL-alanine.

(2) Acetylderivatives of DL-tryptophan, DLleucine and DL-alanine were incubated at $38^{\circ} \mathrm{C}$. for 2 days, at approximately $0.1 \mathrm{~m}$ concentration in water with an appropriate amount of enzyme solution which was prepared from the molded bran.

(3) By this procedure, L-isomers of each amino acid were liberated and the corresponding $\mathrm{D}$-isomers were obtained by acid hydrolysis of the residual acetyl-D-amino acids. Thus, the optical enantiomorphs of tryptophan, leucine and alanine were prepared with a high degree of optical purity.

(4) Acetyl-DL-tryptophan was best resolved by the asymmetric hydrolysis with mold acylase and acetyl-DL-alanine was also a susceptible substrate for mold acylase. AcetylDL-leucine was relatively resistant to the enzyme, as compared with the other acylated amino acids so far resolved. An amount of enzyme two and a half times as large as that for acetyl-DL-tryptophan was required for acetyl-DL-leucine. 